\title{
The Effect of Fuel Injection Pressure on the Diesel Engine Performances
}

\author{
Toto Sugiarto ${ }^{1}$ Wawan Purwanto ${ }^{1 *}$ Dwi Sudarno Putra ${ }^{1}$ Multharizal Khidayat ${ }^{1}$ Alim \\ Kusuma $^{1}$
}

\author{
${ }^{1}$ Universitas Negeri Padang, Indonesia \\ Corresponding author's email: wawan5527@ft.unp.ac.id
}

\begin{abstract}
The purpose of this paper is to reveal the effect of fuel injection pressure on the power and torque of a diesel engine. The research method used is the experimental method. Pressure variations of $110 \mathrm{~kg} / \mathrm{cm}^{2}, 120 \mathrm{~kg} / \mathrm{cm}^{2}$ and $130 \mathrm{~kg} / \mathrm{cm}^{2}$ were applied to a 1981 Chevrolet LUV diesel car. From the experimental results of research conducted at the Automotive Engineering Vehicle Workshop, Faculty of Engineering, Universitas Negeri Padang, it was found that, at a standard pressure of $120 \mathrm{~kg} / \mathrm{cm}^{2}$ obtained an average car power of $29.6 \mathrm{~kW}$ at $4470 \mathrm{RPM}$ and $81.65 \mathrm{Nm}$ of torque at $2455 \mathrm{RPM}$. When the injector pressure is reduced by $110 \mathrm{~kg} / \mathrm{cm}^{2}$, engine power decreases by $17.1 \%$ and torque decreases by $16.2 \%$. When the injector pressure is increased to $130 \mathrm{~kg} / \mathrm{cm} 2$, there is an increase in engine power by $4.05 \%$ and a decrease in torque by $14.89 \%$.
\end{abstract}

Keywords: Diesel Engine, Power, Torque, Injection pressure.

\section{INTRODUCTION}

Internal combustion engines (ICE) are a type of energy conversion engine that is widely used as a vehicle (automotive) or as a driver for industrial equipment [2]. The ICE is a type of heat engine whose combustion process occurs in the combustion cylinder itself, so that the combustion gas that occurs is also the working fluid. ICE works by utilizing heat energy from the combustion process into mechanical energy [3-5]. The air that enters the cylinder, then compressed by the piston. Before the piston reaches the top dead center, fuel is sprayed so that the mixing process occurs with high air temperature. Because the ignition temperature of the fuel has been reached, the ignition process occurs, then the combustion process takes place.

Along with technological developments, diesel engine vehicles are widely used as public and private transportation vehicles. These vehicles have been adapted to the capacity and application of the vehicle itself. Due to the variation in capacity, the diesel engine market has many variations, including a diesel engine that uses a distributor injection pump, In-Line, and most recently using a common rail system. The use of the injection pump is adapted to the vehicle application. Although the common rail system is more effective and efficient than using conventional systems, conventional type pumps are still widely used. Conventional systems are proven to have more stubborn resistance and less complicated maintenance than common rail systems $[6$, 7].

This conventional injection pump in its application, the pressure variation can be adjusted so that the performance of the diesel engine is better, such as advancing the injection, increasing the amount of fuel, adjusting the injector pressure and various other ways to improve the performance of the diesel engine $[8,10]$. By adjusting the diesel fuel injection system, it can increase and even decrease engine performance, if the adjustment is made incorrectly. There are several cases in vehicles, motorbikes and cars that have decreased performance after conducting their own tests using the dynamo mater test. If the vehicle has been modified and hopes that the engine power will increase according to the new components or modified components installed on the vehicle at a price that is not cheap. However, after being tested using a dynamo meter test, the increase in torque from the vehicle did not meet expectations. 


\section{METHOD}

This research is included in real experimental research (true experimental research). This study aims to examine the impact relationship between the treated experimental groups, then compare the results. As explained $[1,9,10,11]$ which states that real experimental research is an experiment that aims, "To investigate the possibility of a causal relationship by applying to one or more experimental groups one or more treatment conditions and comparing the results with one or more treatment conditions and comparing the results with one or more non-treated control groups ". Experimental research is intended to determine the effect and treatment given to the object of research. According to $[14,15]$, the experimental research method can be defined as a research method used to find the effect of certain treatments on others under controlled conditions". The study aimed to compare between the standard state fuel injection pressure compared to when the fuel injection pressure was lowered or increased.

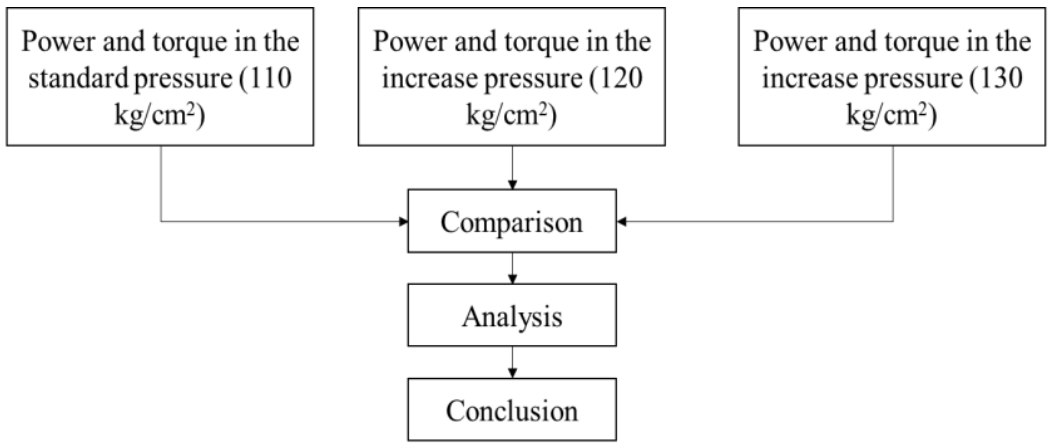

Figure 1. Experimental flowchart

Prior to the implementation of the test, the diesel engine 4 did not comply with the manufacturer's standards without any changes or modifications. The fuel that will be used for testing is bio diesel fuel. The framework of this research is as shown in Figure 1. The data collection technique is to take directly on the 4stroke diesel motor that is being tested using the Dyno Test tool to measure the power and torque produced. Analyzing the data in this study is by using a statistical calculation of the mean or average. According to [1] said in his book "Descriptive statistics is the field of statistical science that studies the procedures for collecting, compiling, presenting data analysis, in order to obtain a clear description and data." Data presentation can be done in various ways, for example in the form of frequency tables or graphs or in the form of certain images with the aim of making it easier to see the main parts of the data group concerned. According to Akhirmen [1] said that "Relative frequency is the frequency expressed in relative numbers. There are two kinds of relative numbers, namely in fraction numbers and in percentage figures.
According to [12] states the object of research is the target or object that will be the subject of discussion in research. The object of this research is a 4-stroke diesel motor unit with the specifications shown in Table 1.

Table 1. Engine specifications

\begin{tabular}{ll}
\hline Specific & Descriptions \\
\hline Engine type & C223 Diesel - Indirect \\
& Injection \\
Ynternational (1981- & $1986)$ \\
Year productions & Solar \\
Fuel & $2,238 \mathrm{cc}$ \\
Capacity & $4($ inline) \\
Total cylinder & $88 \mathrm{~mm} \mathrm{x} 92 \mathrm{~mm}$ \\
Diameter x Step & $45 \mathrm{KW} / 61 \mathrm{HP}) @$ \\
Power $(\mathrm{kW} / \mathrm{HP})$ & $4,000 \mathrm{Rpm}$ \\
& $130 \mathrm{Nm} / 13.3 \mathrm{kgm} @$ \\
Torque $(\mathrm{Nm} / \mathrm{kgm})$ & $2,200 \mathrm{RPM}$ \\
& $120 \mathrm{~kg} / \mathrm{cm}^{2}$ \\
\hline
\end{tabular}

\section{RESULTS AND DISCUSSIONS}

The research was conducted at the Automotive Engineering Vehicle Testing Workshop, FT UNP. From Table 2 it can be seen that the difference in power and torque generated using a standard pressure of $120 \mathrm{~kg} / \mathrm{cm}^{2}$, the pressure is reduced by $110 \mathrm{~kg} / \mathrm{cm}^{2}$ and the pressure is increased by $130 \mathrm{~kg} / \mathrm{cm}^{2}$. From Table 2 it can be seen that the car power increases when the pressure is increased, while when the pressure is lowered the car power decreases. From Table 3 it can be seen that the difference in power and torque generated using a standard pressure of $120 \mathrm{~kg} / \mathrm{cm}^{2}$, the pressure is lowered by $110 \mathrm{~kg} / \mathrm{cm}^{2}$ and the pressure is increased by $130 \mathrm{~kg} / \mathrm{cm}^{2}$. In Table 3 , it can be seen that the power and torque of the car decreased at a pressure of $130 \mathrm{~kg} / \mathrm{cm}^{2}$ compared to the standard pressure, this was due to the effect of the opening of the Throttle Valve which was not optimal at the time of acceleration at the beginning of the test with the Dyno Test. This reduction in power and torque at the same rotation has no effect because the power and torque of a vehicle will be different for each engine speed. 
Table 2. Experimental data in the maximum speeds

\begin{tabular}{cccccc}
\hline No & $\begin{array}{c}\text { Injection } \\
\text { pressure }\left(\mathrm{Kg} / \mathrm{cm}^{2}\right)\end{array}$ & \multicolumn{2}{c}{ Average power } & \multicolumn{2}{c}{ Average torque } \\
& 110 & 24.55 & 4064 & 68.45 & Torque $(\mathrm{Nm})$ \\
\hline 1 & 120 & 29.6 & 4470 & 81.65 & 2453 \\
2 & 130 & 30.8 & 4503 & 69.5 & 3288 \\
3 & & & & & RPM \\
\hline
\end{tabular}

Table 3. Experimental data in the same speeds

\begin{tabular}{|c|c|c|c|c|c|}
\hline \multirow[t]{2}{*}{ No } & \multirow{2}{*}{$\begin{array}{c}\text { Injection } \\
\text { pressure }\left(\mathrm{Kg} / \mathrm{cm}^{2}\right)\end{array}$} & \multicolumn{2}{|c|}{ Average power } & \multicolumn{2}{|c|}{ Average torque } \\
\hline & & Power (Kw) & RPM & Torque (Nm) & RPM \\
\hline 1 & 110 & 22.0 & 4000 & 59.5 & 2200 \\
\hline 2 & 120 & 26.75 & 4000 & 69.0 & 2200 \\
\hline 3 & 130 & 25.5 & 4000 & 62.5 & 2200 \\
\hline
\end{tabular}

Based on the analysis of tables 2 and 3, it is found that the standard pressure compared to the pressure is lowered or increased, resulting in a difference in power and torque generated by the engine, where power and torque decrease if the pressure is reduced to $110 \mathrm{~kg} / \mathrm{cm}^{2}$, and if the pressure is increased to $130 \mathrm{~kg} / \mathrm{cm}^{2}$, then There will be an increase in car power and a decrease in car torque when compared to when the standard pressure is 120 $\mathrm{kg} / \mathrm{cm}^{2}$.

The process of injection or the process of mixing fuel with air in the combustion chamber greatly affects the perfection of the combustion process. By adjusting the adjusting bolt on the nozzle with the aim of increasing the injection pressure which will affect the combustion process. Because with the right or perfect opening and spraying pressure, it will be able to produce optimal combustion in the motor cylinder. Increasing the injection pressure is one of the processes in perfecting the combustion that occurs. The concept of this research is how to inject the same amount of fuel without having to change the duration of injection time. The method taken is by increasing the fuel injection pressure.

The purpose of this study was to determine how much influence the variation in fuel injection pressure on a 4stroke diesel engine has on the power and torque of a vehicle and to find out what fuel injection pressure produces the best power and torque. In this study, vehicle testing was carried out on the Dyno Test tool, the test was carried out twice at each of the same fuel pressure than the average value was taken, this average was used in the analysis of the research data.

Based on the data set in Table 2 it can be seen that under the same engine and working conditions, there is a very clear difference between the standard pressure with the pressure lowered and the pressure increased. Pressure of $130 \mathrm{~kg} / \mathrm{cm}^{2}$ produces the best power at $4500 \mathrm{RPM}$ rotation compared to the standard pressure of $120 \mathrm{~kg} / \mathrm{cm}^{2}$ and the pressure is reduced by $110 \mathrm{~kg} / \mathrm{cm}^{2}$. While a pressure of $120 \mathrm{~kg} / \mathrm{cm}^{2}$ produces the best torque at 2500
RPM rotation compared to a lowered pressure of 110 $\mathrm{kg} / \mathrm{cm}^{2}$ and an increase of $130 \mathrm{~kg} / \mathrm{cm}^{2}$. This shows that there is an influence on the injection pressure treatment. For the torque of the vehicle, a decrease in pressure of $130 \mathrm{~kg} / \mathrm{cm}^{2}$ occurs due to the effect of the opening of the Throttle Valve which is not optimal at the time of acceleration at the beginning of the test with the Dyno Test.

This study is in line with the research conducted by [16]. In this study, it appears that at a higher injection pressure it makes fuel consumption more efficient, and in his research the highest power occurs when the maximum engine speed is $2400 \mathrm{rpm}$ and injection pressure. $15 \mathrm{Mpa}$. Several previous researchers, such as [17-19], related to this study regarding fuel consumption and exhaust gas density in diesel engines. Based on some researchers, the injector pressure has proven that increasing the injector pressure can reduce fuel consumption and increasing the injector pressure can also reduce the density of the diesel motor exhaust gas. The process of fogging diesel fuel through the injector greatly affects the perfect combustion process in the cylinder, because in this diesel motor combustion is given through the heat generated by the compression of the outside air but the flame will not occur without the addition of oxygen. This fogging process is basically mixing fuel with oxygen, for this the fogging process is to obtain the perfect fuel gas in the injector.

The injection pressure indicates the amount required to cloud the fuel. The higher the fogging pressure, the finer the fuel mist conditions or the smaller the mist and the shorter the distance it reaches from the injector. It is said that the better the atomization, the shorter the penetration. The fogging conditions must be adjusted to the amount of compression pressure of the diesel engine. If the injection pressure is increased, the fuel will be easy to evaporate but the penetration is still weak, as a result the fuel will collect around the tip of the injector, so that a lot of fuel lacks oxygen and forms a lot of CO. Conversely, when the pressure is lowered, the penetration 
or dispersion of the fuel is good but slowly evaporates. As a result, a lot of $\mathrm{HC}$ was also formed. $\mathrm{HC}$ and $\mathrm{CO}$ are parts of the fuel that do not produce if it means reducing the amount of fuel that will become heat.

From the discussion, it can be concluded that if the injector pressure is increased it will save fuel because the fogging process is better so that the mixture of fuel and air is perfect, so there is no unburned fuel, which will result in a less concentrated exhaust gas because it does not contain much $\mathrm{HC}$. and $\mathrm{CO}$ and complete combustion will produce heat which will be used to move the piston which will produce good diesel motor power. Conversely, if the injection pressure is lowered, it will make wasteful fuel, poor exhaust gas quality and less powerful motor power. However, the increase in injector pressure must be adjusted to the compression pressure of the engine itself

\section{CONCLUSION}

After carrying out research at the Automotive Engineering Vehicle Testing Workshop with the research object of Power and Torque on the Chevrolet LUV diesel engine, some data needed in this study were obtained. From the data that has been processed, it can be concluded that the average power and torque produced by the Chevrolet LUV diesel engine at a standard pressure of $120 \mathrm{~kg} / \mathrm{cm}^{2}$ is $29.6 \mathrm{Kw}$ Power at $4470 \mathrm{rpm}$ and $81.65 \mathrm{Nm}$ of torque at $2455 \mathrm{rpm}$. When the injector pressure is reduced to $110 \mathrm{~kg} / \mathrm{cm}^{2}$, the power decreases by $17.1 \%$ and the torque decreases by $16.2 \%$. When the injector pressure is increased to $130 \mathrm{~kg} / \mathrm{cm}^{2}$, the power increases by $4.05 \%$ and the torque decreases by $14.89 \%$. By increasing and decreasing the injector pressure, it can help 4 stroke diesel engine consumers to adjust the power and torque of the vehicle as needed.

\section{REFERENCES}

[1] Akhirmen, "Statistik Deskriptif". Padang: IKIP Padang Press, 1997.

[2] Toyota Astra, "New Step 1 Training Manual, Jakarta: PT Toyota-Astra Motor, 1995.

[3] Toyota Astra, "New Step 2 Training Manual", Jakarta: PT Toyota-Astra, 1995.
[4] Daryanto, "Teknik Pesawat Tenaga", Jakarta: Bumi Aksara, 1991.

[5] D. I. Setyabudi, “Teknik Motor Diesel”. Bandung: Alabeta, 2015.

[6] H. Maksum. Reffles. Wawan, P, "Teknologi Motor Bakar”, Padang: UNP Press, 2012.

[7] R. Z. Arifin, "Sistem Bahan Bakar Motor Diesel”, Yogyakarta: Graha ilmu, 2011.

[8] Rakhmawati, "Pengaruh Variasi Tekanan Injeksi Pada Unjuk Kerja Motor Diesel dengan Bahan Bakar Alternatif Biodiesel Minyak Biji Kapuk (Klenteng Kapuk)", Semarang: UNNES, 2015.

[9] Riduwan, "Dasar-Dasar Statistika", Bandung: Alfabeta, 2016.

[10] Rinaldi, "Pengaruh tekanan injektor terhadap konsumsi bahan bakar pada engine Mitsubishi L 300 Diesel", Padang: UNP, 2013.

[11] Sugiono, "Metode Penelitian Kuantitatif, Komulatif dan R\&D”, Bandung: Alfabeta, 2012.

[12] S. Arikunto, "Prosedur Penelitian Suatu Pendekatan Praktik”, Jakarta: Rineka Cipta, 2006.

[13] S. Karnowo, S.M. B Respati, "Teknik Mesin Industri", Jakarta: Direktorat Pembinaan Sekolah Menengah Kejuruan, 2008.

[14] S. Sumadi. "Metodologi Penelitian Cetakan Ke 25", Jakarta: Raja grafindo Persada. 2014.

[15] S, Siregar, "Metode Penelitian Kuantitatif", Jakarta: Kencana. 2014.

[16] T. Sugiarto, Pegaruh Pemajuan Saat Penginjksian Terhadap Ketebalan Asap Mesin Diesel. Automotive Engineering Education Journals, 2015.

[17] Wakhinuddin, "Motor Diesel". Padang: UNP Press, 2009

[18] Y. Alam, "Pengaruh variasi tekanan penyemprotan dengan penambahan putaran ulir nosel terhadap konsumsi bahan bakar, daya mesin dan kepekatan gas buang pada isuzu panther higrade. Malang. UNM, 2015. 